Bond University

Research Repository

\title{
Duty loads carried by the LA sheriff's department officers
}

Dulla, Joseph; Baran, Kate; Pope, Rodney; Orr, Rob Marc

Published in:

Journal of Science and Medicine in Sport

DOI:

10.1016/j.jsams.2017.09.010

Licence:

CC BY-NC-ND

Link to output in Bond University research repository.

Recommended citation(APA):

Dulla, J., Baran, K., Pope, R., \& Orr, R. M. (2017). Duty loads carried by the LA sheriff's department officers.

Journal of Science and Medicine in Sport, 20(Suppl. 2), S5-S6. https://doi.org/10.1016/j.jsams.2017.09.010

\footnotetext{
General rights

Copyright and moral rights for the publications made accessible in the public portal are retained by the authors and/or other copyright owners and it is a condition of accessing publications that users recognise and abide by the legal requirements associated with these rights.
}

For more information, or if you believe that this document breaches copyright, please contact the Bond University research repository coordinator. 


\title{
Duty loads carried by the LA Sheriff's Department Officers
}

\author{
Dulla, Joe ${ }^{1}$, Baran, Kate ${ }^{2}$, Pope, Rodney ${ }^{3}$, Orr, Robin ${ }^{4}$ \\ ${ }^{1}$ LA Sheriff's Department, Los Angeles, CA, United States of America \\ 2-4 Bond University, Gold Coast, QLD, Australia \\ 3,4 Tactical Research Unit, Bond University, Gold Coast, QLD, Australia \\ 1 JMDulla@lasd.org \\ 2 kbaran@student.bond.edu.au \\ 3 rpope@bond.edu.au \\ ${ }^{4}$ rorr@bond.edu.au
}

Purpose: Law enforcement officers (LEO) are required to carry and wear additional functional and protective equipment which may include, but is not restricted to, body armour, duty belts, radio, weapons and many other personal protection items. While an occupational necessity, these additional loads may negatively impact task performance and increase the risk of musculoskeletal injuries. The aim of this study was to profile the loads carried by LA Sheriff's Department (LASD) deputies who attended patrol training and investigate whether any gender differences existed. Methods:

Retrospective data for 98 Sheriff's Deputies (male $n=78$, female $n=20$ ) from the LASD who were attending Patrol School were analysed for this study. Participants were required to complete a questionnaire detailing age, current daily duty loads, an itemised listing of duty load, and how many years they had been sworn as an officer. Following the survey, participants were weighed in their uniforms with (absolute load) and without (body weight) duty load, with the resultant load weight recorded in kg. Results: The mean absolute load carried by LASD officers was $9.98 \pm 1.92 \mathrm{~kg}$ (range = $5.73 \mathrm{~kg}-16.27 \mathrm{~kg}$ ) and the mean relative load was $11.91 \pm 2.77 \%$ (range $=5.65-21.04 \%$ ) of body weight. In absolute terms, female officers carried significantly lighter loads compared to male officers (female mean load $=8.72 \pm 1.39 \mathrm{~kg}$, male mean load=10.30 $\pm 1.92 \mathrm{~kg} ; \mathrm{p}<.001$ ). When load weight was expressed in relative terms, there were no significant differences between female and male officer load weights (female mean relative load $=12.44 \pm 2.85 \%$, male mean relative load $=11.78 \pm 2.75 \%$, $\mathrm{p}=.347$ ). Mandated equipment included a primary handgun (loaded), two handgun magazines (loaded), Oleoresin Capsicum (OC) spray, a handheld radio, two sets of handcuffs and an impact weapon such as a baton. Common miscellaneous items carried in duty belts included: knives, a tourniquet, keys, flashlights, extra magazines, Taser battery clips, rescue tools- Conclusion: While the loads carried by LEO's are typically lower than those carried by military personnel, the chronic wearing of these loads on an ongoing daily basis can lead to a high risk of injury and may also negatively impact on their ability to perform tasks effectively and safely. While female LEO's may carry lighter absolute loads, their loads are commensurate with those of male LEO when expressed as a relative load. 